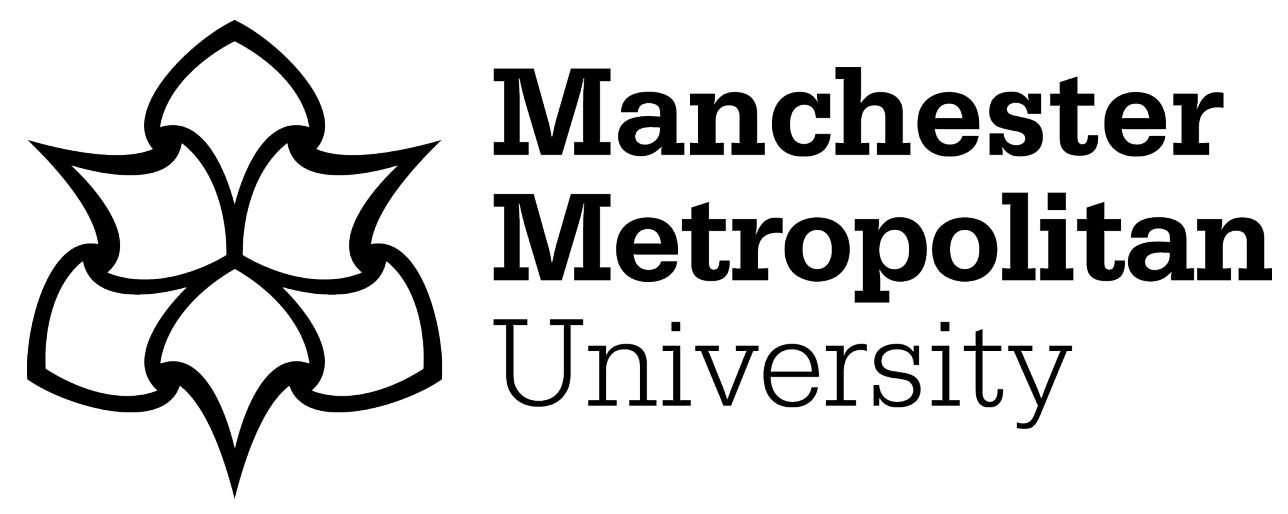

Hedin, C, van der Gast, C, Rogers, G, McCartney, S, Stagg, AJ, Lindsay, JO and Whelan, K (2014) Siblings of Crohn's Disease Patients Exhibit a Pathologically Relevant Dysbiosis: Examination of Mucosal Microbiota Communities Using 16S rRNA Gene Pyrosequencing. In: 55th Annual Meeting of the Society-for-Surgery-of-the-Alimentary-Tract (SSAT) / Digestive Disease Week (DDW), 03 May 2014 - 06 May 2014, Chicago, IL.

Downloaded from: https://e-space.mmu.ac.uk/621045/

Version: Accepted Version

Publisher: W B SAUNDERS CO-ELSEVIER INC

Please cite the published version 


\section{Siblings of Crohn's Disease Patients Exhibit a Pathologically Relevant Dysbiosis: Examination of Mucosal Microbiota Communities Using 16S rRNA Gene Pyrosequencing}

Charlotte Hedin, Christopher van der Gast, Geraint Rogers, Sara McCartney, Andrew J. Stagg, James O. Lindsay, Kevin Whelan

Background Reduced mucosal concentrations of Faecalibacterium prausnitzii predict disease recurrence in patients with Crohn's disease (CD). Siblings of CD patients have elevated risk of developing $C D$ and share aspects of disease phenotype compared with healthy controls $(\mathrm{HC})$, including dysbiosis in the faecal microbiota.[1] No study has compared the mucosal microbiota of $C D$ siblings with unrelated healthy controls. Aim: to determine whether dysbiosis is present in the mucosal microbiota of siblings of CD patients with reference to $\mathrm{HC}$, and to apply $16 \mathrm{~S}$ rRNA gene pyrosequencing in order to accomplish a more comprehensive characterisation of that dysbiosis.

Methods Rectal biopsies were taken from 21 patients with quiescent $C D, 17$ of their healthy siblings and 19 unrelated HC. Total DNA was extracted using phenol/chloroform based method. The V1 to V3 region of the bacterial $16 \mathrm{~S}$ ribosomal RNA gene was amplified using PCR, and microbiota composition resolved by 454 pyrosequencing. Sequence processing and analyses were performed using the open source Mothur software package (www.mothur.org).

Results For each group the resulting species in the microbiota were classified into core (common and abundant among similar subjects) versus infrequent and rare.[2] In terms of both microbial diversity (measured by both the ShannonWiener and Simpson's indexes of diversity) and species richness, the core mucosal microbiota of both siblings and CD patients were significantly less diverse than HC. Although the diversity of the rare microbiota was lower in $\mathrm{CD}$ compared with $\mathrm{HC}$, there was no difference in diversity of rare microbiota between siblings and HC. Metacommunity profiling using the Bray-Curtis (SBC) index of similarity with unweighted pair group averages showed that the core microbial metacommunity of siblings was more similar to $C D(S B C=0.70)$ than to $H C$, whereas the rare microbial metacommunity of siblings was more similar to $\mathrm{HC}(\mathrm{SBC}=0.42)$. As in $\mathrm{CD}$ patients, the species that contributed most to the dissimilarity between healthy siblings and $\mathrm{HC}$ was F. prausnitzii, Table 1.

Conclusions This is the first in depth case-control study of the mucosal microbiota in the siblings of $C D$ patients. We report a dysbiosis characterised by reduced diversity of core microbiota and lower abundance of $F$. prausnitzii. Given that siblings of $C D$ patients have elevated risk of developing $C D$, this dysbiosis in otherwise healthy people implicates microbiological processes in CD pathogenesis and risk.

References [1] Hedin C et al. 2013, Siblings of Patients With Crohn's Disease Have a Distinct Microbiological and Immune Phenotype Compared to Healthy Controls: Insights Into Disease Pathogenesis, Gastroenterology, Vol. 144, Suppl. 1, S57-8 [2] van der Gast CJ, et al. 2011, Partitioning core and satellite taxa from within cystic fibrosis lung bacterial communities., ISME J, Vol. 5, 780-791 
Table 1. Similarity of Percentages (SIMPER) analysis of bacterial community similarity (BrayCurtis) between whole metacommunities for siblings and healthy controls

\begin{tabular}{|c|c|c|c|c|c|}
\hline Name & $\begin{array}{c}\text { Siblings } \\
\text { Mean } \\
\text { abundance } \\
(\%)\end{array}$ & $\begin{array}{c}\text { Healthy } \\
\text { Mean } \\
\text { abundance } \\
\quad(\%)\end{array}$ & $\begin{array}{c}\text { Average } \\
\text { Dissimimilarity } \\
(\%)\end{array}$ & $\begin{array}{c}\text { Contribution } \\
\text { to } \\
\text { dissimilarity } \\
(\%)\end{array}$ & $\begin{array}{l}\text { Cumulative } \\
\text { contribution to } \\
\text { dissimilarity } \\
(\%)\end{array}$ \\
\hline $\begin{array}{c}\text { Faecalibacterium } \\
\text { prausnitzii }\end{array}$ & 23.4 & 30.0 & 10.4 & 18.9 & 18.9 \\
\hline $\begin{array}{l}\text { Escherichia } \\
\text { fergusonii }\end{array}$ & 9.6 & 3.9 & 5.8 & 10.6 & 29.5 \\
\hline $\begin{array}{c}\text { Sutterella } \\
\text { wadsworthensis }\end{array}$ & 5.8 & 8.6 & 5.2 & 9.4 & 38.9 \\
\hline Shigella flexneri & 6.9 & 3.5 & 4.6 & 8.4 & 47.3 \\
\hline $\begin{array}{c}\text { Bacteroides } \\
\text { vulgatus }\end{array}$ & 7.3 & 7.9 & 4.6 & 8.4 & 55.7 \\
\hline $\begin{array}{l}\text { Eubacterium } \\
\text { rectale }\end{array}$ & 6.1 & 9.5 & 3.9 & 7.0 & 62.8 \\
\hline $\begin{array}{l}\text { Oscillospira } \\
\text { guilliermondii }\end{array}$ & 7.6 & 8.1 & 3.9 & 7.0 & 69.8 \\
\hline Bacteroides dorei & 5.5 & 0.0 & 3.0 & 5.4 & 75.2 \\
\hline $\begin{array}{l}\text { Ruminococcus } \\
\text { gnavus }\end{array}$ & 4.7 & 4.0 & 2.2 & 4.1 & 79.3 \\
\hline $\begin{array}{c}\text { Bacteroides } \\
\text { uniformis }\end{array}$ & 1.9 & 2.8 & 2.2 & 3.1 & 82.4 \\
\hline Roseburia faecis & 3.7 & 2.4 & 1.7 & 3.0 & 85.4 \\
\hline $\begin{array}{l}\text { Coprococcus } \\
\text { eutactus }\end{array}$ & 0.0 & 2.2 & 1.2 & 2.2 & 87.7 \\
\hline $\begin{array}{c}\text { Shigella } \\
\text { dysenteriae }\end{array}$ & 0.0 & 2.0 & 1.2 & 2.1 & 89.8 \\
\hline Blautia producta & 1.7 & 1.9 & 0.0 & 1.8 & 91.6 \\
\hline
\end{tabular}

